Niu, C-I \& Fraenkel-Conrat, H. (1955). J. Amer. chem. Soc. 77, 5882 .

Phillips, D. M. P. (1958). Biochem. J. 68, 35.

Phillips, D. M. P. \& Johns, E. W. (1959). Biochem. J. 72, 538.

Phillips, D. M. P. \& Simson, P. (1961). Biochem. J. 78, 32 P.

Sanger, F. (1945). Biochem. J. 39, 507.

Satake, K. \& Luck, J. M. (1959). Fed. Proc. 18, 316.
Satake, K., Rasmussen, P. S. \& Luck, J. M. (1960). J. biol. Chem. 235, 2801.

Vendrely, R., Knobloch-Mazen, A. \& Vendrely, C. (1960). Biochem. Pharmucol. 4, 19.

Wilkins, M. H. F., Zubay, G. L. \& Wilson, H. R. (1959a). Trans. Faraday Soc. 55, 497.

Wilkins, M. H. F., Zubay, G. L. \& Wilson, H. R. (1959b). J. molec. Biol. 1, 179.

Biochem. J. (1962) 82, 241

\title{
Purification of Human Plasminogen
}

\author{
By M. DERECHIN* \\ Lister Institute of Preventive Medicine, Chelsea Bridge Road, London, S.W. 1
}

(Received 11 July 1961)

Plasminogen is the inactive precursor of plasmin, a proteolytic enzyme of plasma. The euglobulin fraction of serum was first used as a source of plasminogen after Milstone's (1941) description of the preparation of the 'lytic factor'. Remmert \& Cohen (1949) purified plasminogen by two precipitations at $\mathrm{pH} 5.3$ at different ionic strengths, followed by adsorption on kaolin and elution with phosphate buffer. Christensen \& Smith (1950) extracted plasminogen from Cohn's fraction III by means of $0 \cdot 2 \mathrm{~N}$-sulphuric acid. Kline (1953) purified plasminogen by extracting Cohn's fraction III with $0.05 \mathrm{~N}$-sulphuric acid, subsequently adjusting the extract to $\mathrm{pH} 11$ with $\mathrm{NaOH}$ and then precipitating plasminogen with a small amount of phosphate buffer, pH 6. Finally, the precipitated protein was redissolved and crystallized at pH 8.2.

Wallen \& Bergström (1960) precipitated plasminogen from Cohn's fraction II + III at low ionic strength at $\mathrm{pH} 5 \cdot 3$. The precipitate was dissolved in ammonium acetate buffer, adsorbed on a column of diethylaminoethylcellulose and eluted by $a$ stepwise procedure with ammonium acetate buffers, pH 9 and pH 4, containing 0.01 m-lysine.

Hagan, Ablondi \& De Renzo (1960) used carboxymethylcellulose to purify plasminogen prepared by the Kline procedure. The preparation was adsorbed from solution in formate buffer, $\mathrm{pH} 3$, and gradient elution yielded plasminogen at either pH 2.4-1.8 or 5.0-5.9.

The greatest increase in activity relative to plasma or serum has been claimed for preparations obtained by methods involving acid extraction (Kline, 1953; Hagan et al. 1960). However, such preparations are insoluble at neutral $\mathrm{pH}$ (Alk-

* Present address: Department of Colloid Science, Free School Lane, Cambridge, England. jaersig, Fletcher \& Sherry, 1958), although the original material is soluble in plasma and the reported isoelectric point is about pH 5.6 (Shulman, Alkjaersig \& Sherry, 1958).

A procedure for purifying plasminogen described here consists of steps which are milder than those entailing the treatment of the proteins with sulphuric acid or sodium hydroxide at extreme $\mathrm{pH}$ values. A final adsorption with diethylaminoethylcellulose, based on the method of Wallen \& Bergström (1960), provides material soluble at neutral pH with high spocific activities.

\section{MATERIALS AND METHODS}

Reagents. These were: I-lysine monohydrochloride (Hopkin and Williams Ltd.); L-arginine hydrochloride (Hopkin and Williams Ltd.); e-amino-n-hexanoic acid (L. Light and Co. Ltd.); diethylaminoethylcellulose, Whatman (DE 50).

Buffers. The following were used: acetate-phosphate buffers (Kekwick \& Mackay, 1954): $\mathrm{pH} 4: \mathrm{Na}_{2} \mathrm{HPO}_{4}$ (7 mM), acetic acid (43 mM); pH 5.15: $\mathrm{Na}_{2} \mathrm{HPO}_{4}$ (11 mM), acctic acid (23 mM). Citrate buffer (Kekwick. Mackay, Nance \& Record, 1955), I l.0: trisodium citrate (0.164 M), citric acid (6 mM). Phosphate buffers (Kolthoff, 1937): pH 6.5-8.0, I 0.1-0.3; NaCl-phosphate buffers prepared by mixing 9 vol. of $0.2 \mathrm{M}-\mathrm{NaCl}$ with 1 vol. of phosphate buffor, $I 0 \cdot 2$, covering the range 6.5-8.0. Sodium chloridoveronal-buffers, prepared by mixing 8 vol. of $0.2 \mathrm{M}-\mathrm{NaCl}$ with 2 vol. of veronal buffers (Kolthoff, 1937) covering the range 6.5-9.0. Ammonium acetate buffer: $57 \cdot 6 \mathrm{ml}$. of acetic acid was added to $1800 \mathrm{ml}$. of water and then conc. $\mathrm{NH}_{3}$ solution [Hopkin and Williams Ltd.; Analytical Reagent, $35 \%(\mathrm{w} / \mathrm{v}) \mathrm{NH}_{3}$ ] was added until the $\mathrm{pH}$ of the mixture was 9.0; this solution was designated $0.5 \mathrm{M}$ ammonium acetate buffer and was used as a stock solution from which diluted buffers were made. Glycine-NaOH$\mathrm{NaCl}$ buffer (Miller \& Golder, 1950), pH 9.2, I 0.1 : glycine (17 mM), $\mathrm{NaOH}$ (3 mM), $\mathrm{NaCl}$ (97 mM).

Bioch. 1962, 82 
Diethyl ether. The ether used for the precipitation was anaesthetic grade but free from antiperoxidants. Peroxides were not detected with KI (British Pharmacopoeia).

Deterninalion of $\mathrm{pH}$. $\mathrm{pH}$ values were determined electrometrically with a MacInnes-type glass electrode, the outer chamber of which contained $0.05 \mathrm{M}$-potassium hydrogen phthalate; $3.5 \mathrm{M}-\mathrm{KCl}$-calomel cells were used as reference electrodes and a buffer containing $0.09 \mathrm{M}-\mathrm{KCl}$ and $0.01 \mathrm{M}-\mathrm{HCl}$ assumed to have a $\mathrm{pH} 2.10$ was used as a standard. Measurements were made at room temperature with a valve potentiometer, having an accuracy of $\pm 0.01 \mathrm{pH}$ unit. In systems containing ether the $\mathrm{pH}$ values given are apparent and no attempt was made to correct for the effect of the ether on the measurements.

b'stimation of nitrogen. Samples of protein solutions were digested in $2 \mathrm{ml}$. of $\mathrm{H}_{2} \mathrm{SO}_{4}$ (microanalytical reagent) with the catalyst mixture recommended by Chibnall, Rees \& Williams (1943) and estimations of $N$ were made according to Ma \& Zuazaga (1942).

Plasminogen assay. Plasminogen was estimated after converting it into plasmin with streptokinase, as described by Derechin (1961). The amount of enzyme in the reaction mixture was adjusted to ensure that three samples taken at intervals of 3-5 min. from one another would each give estimates falling on the linear portion of the reaction curve. These samples $(4 \mathrm{ml}$.) were pipetted into $2 \mathrm{ml}$. of $1.7 \mathrm{M}$ $\mathrm{HClO}_{4}$ at room temperature and shaken at intervals for 20-30 min. The suspension was filtered and the extinction of the filtrate was read at $276 \mathrm{~m} \mu$ in $1 \mathrm{~cm}$. cells with a Unicam model SP. 600 spectrophotometer. In all, four samples were taken, the first after proteolysis for $10 \mathrm{~min}$. being used as a blank. The plasmin 'unit' here is that amount of enzyme which gives rise to an increase of 0.001 unit of extinction/min., of the filtrate, during the linear part of the reaction curve with casein $(2 \mathrm{~g} . / 100 \mathrm{ml}$.) in phosphate buffer, pH $7.6(I 0.2)$, at $40^{\circ}$. The specific activity of a preparation is defined by the equation: specific activity $=10^{3} S F / N$, where $S$ is the slope of the linear portion of the reaction curve in units of extinction/min., $F$ the dilution factor, and $N \mathrm{mg}$. of nitrogen $/ \mathrm{ml}$. of the plasminogen solution assayed.

Plasma. Out-dated citric acid-sodium citrato-dextrose plasma was used throughout.
Electrophoresis studies. The electrophoresis patterns were obtained in the Tiselius (1937) apparatus with the cylindrical-lens schlieren system described by Philpot (1938). Protein solutions were run at $0^{\circ}$, for the first hour at $10 \mathrm{~mA}$ followed by $3 \mathrm{hr}$. at $15 \mathrm{~ms}$. The patterns were photographed at intervals with Ilford half-tone panchromatic plates, with a high-pressure mercury arc as a source of light, and a suitable filter to isolate light of a wavelength of $546 \mathrm{~m} \mu$. One run was carried out in the Perkin-Elmer version of the Tiselius (1937) apparatus for $1 \mathrm{hr}$. at $15 \mathrm{~mA}$.

\section{EXPERIMENTAL AND RESULTS}

\section{Precipitation of fibrinogen from plasma}

The fibrinogen was precipitated from plasma at $\mathrm{pH} \mathbf{7 \cdot 7}$ with $11 \%(\mathrm{v} / \mathrm{v})$ ether at $0^{\circ}$ as described by Kekwick et al. (1955). The mixture was centrifuged for $45 \mathrm{~min}$. at $0^{\circ}$, 30 min. after adjusting the precipitation conditions, and the supernatant solution (S1) was siphoned off.

\section{Precipitation of crude plasminogen (fraction $P 1$ ) from $S 1$}

The solution S1 was adjusted to $\mathrm{pH} \mathrm{5.3-5.4}$ with $0.5 \mathrm{M}$ acetic acid and diluted with an equal volume of water at $0^{\circ}$. The precipitate that forms contains plasminogen and prothrombin and by diluting the S1 with an equal volume of water $J$ is lowered sufficiently to produce a maximum precipitation of plasminogen. The mixture was centrifuged $30 \mathrm{~min}$. after the precipitation conditions had been adjusted. The recovery of plasminogen was the same after $30 \mathrm{~min}$. equilibration as after $16 \mathrm{hr}$, although more protein precipitated after the longer period.

Differences in the yicld and specific activity were not great when the $\mathrm{pH}$ of precipitation was varied from 5.05 to 5.4 but the recovery was a little higher at $\mathrm{pH} 5 \cdot 15$ than at other pH values. However, at the next stage of the fractionation the yield of plasminogen obtained was much lower from material precipitated at $\mathrm{pH} 5 \cdot 15$ than from that precipitated at $\mathrm{pH} 5 \cdot 3-5 \cdot 4$; the latter was consequently preferred.

\section{Table 1. Effect of $\mathrm{pH}$ and temperature on the precipitation of plasminogen from citrate buffers}

Column (6) gives the calculated amount of $N$ in fraction derived from 11 . of original plasma. Column (8) gives the calculated total activity derived from 11 . of original plasma. Fraction P1 was the starting material. The precipitates P2 were collected after $16 \mathrm{hr}$. equilibration (Expts. 30 and 32) or 30 min. equilibration (Expt.

\begin{tabular}{|c|c|c|c|c|c|c|c|c|}
\hline $\begin{array}{l}34) . \\
\text { Expt. } \\
\text { no. } \\
\text { (1) }\end{array}$ & $\begin{array}{c}\text { Fraction } \\
\text { (2) }\end{array}$ & $\begin{array}{l}\text { pH } \\
\text { (3) }\end{array}$ & $\begin{array}{c}\text { Temp. } \\
\text { (4) }\end{array}$ & $\begin{array}{c}\text { Ether } \\
\text { (\%) } \\
\text { (5) }\end{array}$ & $\begin{array}{c}\text { Nitrogen } \\
\text { (mg./l. of } \\
\text { plasma) } \\
(6)\end{array}$ & $\begin{array}{c}\text { Specific } \\
\text { activity } \\
(7)\end{array}$ & $\begin{array}{l}\text { Activity } \\
\text { (units/l. of } \\
\text { plasma) } \\
\text { (8) }\end{array}$ & $\begin{array}{c}\text { Recovery } \\
(\%) \\
(9)\end{array}$ \\
\hline 30 & $\begin{array}{l}\text { P2 } \\
\text { P2 } \\
\text { P2 }\end{array}$ & $\begin{array}{l}\mathbf{5 \cdot 3} \\
\mathbf{5} \cdot 8 \\
\mathbf{6 \cdot 5}\end{array}$ & $\begin{array}{l}\mathbf{0}^{\circ} \\
\mathbf{0} \\
\mathbf{0}\end{array}$ & $\begin{array}{l}\mathbf{5} \\
\mathbf{5} \\
\mathbf{5}\end{array}$ & $\begin{array}{l}647 \\
386 \\
203\end{array}$ & $\begin{array}{l}114 \\
144 \\
198\end{array}$ & $\begin{array}{l}95000 \\
72000 \\
55000\end{array}$ & $\begin{array}{l}\mathbf{9 8} \\
\mathbf{7 5} \\
\mathbf{5 7}\end{array}$ \\
\hline 32 & $\begin{array}{l}\text { P2 } \\
\text { P2 } \\
\text { P2 }\end{array}$ & $\begin{array}{l}6 \cdot 8 \\
7 \cdot 4 \\
7 \cdot 7\end{array}$ & $\begin{array}{l}\mathbf{0} \\
\mathbf{0} \\
\mathbf{0}\end{array}$ & $\begin{array}{l}10 \\
10 \\
10\end{array}$ & $\begin{array}{r}158 \\
59 \\
41\end{array}$ & $\begin{array}{l}264 \\
\mathbf{3 3 0} \\
\mathbf{3 7 8}\end{array}$ & $\begin{array}{l}41800 \\
19500 \\
15000\end{array}$ & $\begin{array}{l}39 \\
18 \\
14\end{array}$ \\
\hline 34 & $\begin{array}{l}\text { P2 } \\
\text { P2 }\end{array}$ & $\begin{array}{l}6.5 \\
6.5\end{array}$ & $\begin{array}{r}-3 \\
0\end{array}$ & $\begin{array}{l}10 \\
10\end{array}$ & $\begin{array}{l}410 \\
315\end{array}$ & $\begin{array}{l}246 \\
252\end{array}$ & $\begin{array}{r}110000 \\
79000\end{array}$ & $\begin{array}{l}96 \\
68\end{array}$ \\
\hline 30 & $\mathbf{P l}$ & - & - & - & 722 & 135 & 97000 & 100 \\
\hline 32 & P1 & - & - & - & 630 & 170 & 107000 & 100 \\
\hline 34 & P1 & - & - & - & 625 & 185 & 115000 & 100 \\
\hline
\end{tabular}


Table 2. Effect of protein concentration, ionic strength and $\mathrm{pH}$ on the precipitation of plasminogen from fraction $P 2$ dissolved in acetate-phosphate buffer

Column (2) gives the total protein concentration used in the precipitation mixture. Column (3) gives values measured after the conditions had been adjusted. The values in columns (6) and (7) are relative to those of the starting fraction P2 (specific activity was 354 in Expts. 43 and 58, and 336 in Expt. 44).

\begin{tabular}{|c|c|c|c|c|c|c|}
\hline $\begin{array}{l}\text { Expt. } \\
\text { no. } \\
(1)\end{array}$ & $\begin{array}{l}\text { Protein } \\
\text { (g. } / 100 \mathrm{ml} .) \\
\text { (2) }\end{array}$ & $\begin{array}{l}\mathrm{pH} \\
(\mathbf{3})\end{array}$ & $\begin{array}{l}I \text { of pptn. } \\
\text { mixture } \\
\text { (4) }\end{array}$ & $\begin{array}{l}\text { Specific } \\
\text { activity } \\
\text { (5) }\end{array}$ & $\begin{array}{c}\text { Yield of } \mathbf{N} \\
(\%) \\
(\mathbf{6})\end{array}$ & $\begin{array}{c}\text { Activity } \\
(\%) \\
(7)\end{array}$ \\
\hline 43 & $\begin{array}{l}0.40 \\
0.22 \\
0.11 \\
0.07\end{array}$ & $\begin{array}{l}5 \cdot 05 \\
5 \cdot 08 \\
5 \cdot 09 \\
5 \cdot 05\end{array}$ & $\begin{array}{l}0.01 \\
0.01 \\
0.01 \\
0.01\end{array}$ & $\begin{array}{l}420 \\
474 \\
498 \\
534\end{array}$ & $\begin{array}{l}49 \\
39 \\
34 \\
27\end{array}$ & $\begin{array}{l}59 \\
52 \\
48 \\
41\end{array}$ \\
\hline 58 & $\begin{array}{l}0.30 \\
0 \cdot 15 \\
0.09\end{array}$ & $\begin{array}{l}5 \cdot 12 \\
5 \cdot 15 \\
5 \cdot 10\end{array}$ & $\begin{array}{l}0.03 \\
0.03 \\
0.03\end{array}$ & $\begin{array}{l}432 \\
492 \\
492\end{array}$ & $\begin{array}{l}53 \\
47 \\
45\end{array}$ & $\begin{array}{l}72 \\
72 \\
68\end{array}$ \\
\hline 44 & $\begin{array}{l}0.045 \\
0.045 \\
0.045 \\
0.045\end{array}$ & $\begin{array}{l}5 \cdot 02 \\
5 \cdot 11 \\
5 \cdot 23 \\
5 \cdot 28\end{array}$ & $\begin{array}{l}0.02 \\
0.02 \\
0.02 \\
0.02\end{array}$ & $\begin{array}{l}450 \\
510 \\
492 \\
444\end{array}$ & $\begin{array}{l}31 \\
38 \\
40 \\
42\end{array}$ & $\begin{array}{l}42 \\
57 \\
59 \\
56\end{array}$ \\
\hline
\end{tabular}

Table 3. Effect of the final temperature on the plasminogen remaining in the bottom layer (fraction $B L$ )

The last two columns give the percentages of nitrogen and activity yielded relative to those of the starting fraction P3 (specific activity 480). The solution was in phosphato$\mathrm{NaCl}(\mathrm{pH} 7 \cdot 5)$, protein concentration $0.07 \mathrm{~g} . / 100 \mathrm{ml}$.

$\begin{array}{cccc}\begin{array}{c}\text { Final temp. } \\ \text { of mixture }\end{array} & \begin{array}{c}\text { Specific } \\ \text { activity }\end{array} & \begin{array}{c}\text { Yield of } \\ \text { N (\%) }\end{array} & \begin{array}{c}\text { Activity } \\ (\%)\end{array} \\ -3^{\circ} & 1500 & 11 & 34 \\ 0 & 1380 & 15 & 44 \\ 2 & 1260 & 16 & 43 \\ 4 & 940 & 26 & 51 \\ 9 & 850 & 28 & 50 \\ 17 & 690 & 68 & 98\end{array}$

\section{Fractionation of fraction $P 1$ in citrate buffers (fraction P2)}

It was shown in a procedure devised for preparing plasminogen-free fibrinogen (Kekwick et al. 1955) that, by extracting crude fibrinogen with citrate buffers of suitable ionic strength between $\mathrm{pH} 6.1$ and 6.5 at $0^{\circ}$, more plasminogen remained in the undissolved residue than was extracted. The possibility of using similar citrate buffers to purify plasminogen was explored in the range 5:3-7.7.

Fraction Pl was dissolved in citrate buffers over a $\mathrm{pH}$ range of 5.3-6.5 and plasminogen was precipitated from these solutions with $5 \%(v / v)$ ether at $0^{\circ}$. Precipitations at $\mathrm{pH}$ values higher than 6.5 were carried out by dissolving the fraction $\mathrm{Pl}$ in $9 \mathrm{~mm}$-trisodium citrate and adjusting the $\mathrm{pH}$ of the protein solution electrometrically to the required value with $0.02 \mathrm{~N}-\mathrm{NaOH}$ and adding $10 \%(\mathrm{v} / \mathrm{v})$ ether. The precipitate obtained in this way was designated fraction P2.

The specific activity of the fraction P 2 increases on increasing the $\mathrm{pH}$ of the precipitation (Table 1); however, at $\mathrm{pH}$ values higher than 7 , recoveries of the total activity were low.

The recovery of activity was influenced by the temperature of precipitation, the highest yields being obtained at $-3^{\circ}$ and at $\mathrm{pH}$ values not higher than 6.5 (Table 1). Neither varying the protein concentration between 0.5 and $1.8 \mathrm{~g} . / 100 \mathrm{ml}$. nor $I$ between 0.06 and 0.11 had any striking influence on the results.

The standard conditions chosen for the precipitation of fraction $\mathrm{P} 2$ were, accordingly, $\mathrm{pH} \mathrm{6 \cdot 3-}$ $6.5, I 0.06$, protein concentration $1-1.5 \mathrm{~g} . / 100 \mathrm{ml}$., ether $10 \%(\mathrm{v} / \mathrm{v})$ at $-3^{\circ}$. The precipitation mixture was centrifuged for $120 \mathrm{~min}$. at $1500 \mathrm{rev} . / \mathrm{min}$. at $-3^{\circ}, 30 \mathrm{~min}$. after the conditions were adjusted. Yields were between 90 and $100 \%$, the specific activity being increased by a factor of about 1:5.

\section{Fractionation of fraction $P 2$ in acetate phosphate buffers (fraction $P$ 3)}

Fraction P2 was suspended in a volume of acetatephosphate buffer, $\mathrm{pH} 4$, about $20-30 \%$ of that of the original plasma, the resulting mixture having a $\mathrm{pH}$ of 4.2-4.3. Some $10 \%$ of the material did not dissolve and was removed by centrifuging. No plasminogon could be detected in the insoluble material.

The clarified solution was then titrated electrometrically to the desired $\mathrm{pH}$ with acetate-phosphate buffer, $\mathrm{pH} 6$, diluted with water to a selected ionic strength and equilibrated at $0^{\circ}$ for $16 \mathrm{hr}$. The supernatant solution was siphoned off and discarded and the precipitate separated by centrifuging for $40 \mathrm{~min}$. at $1500 \mathrm{rev} . / \mathrm{min}$. at $0^{\circ}$. The fraction prepared in this way was designated P3.

From pH 5.1 to 5.4 the recovery of activity varied very little, but at $\mathrm{pH} 5.0$ the recovery was $30 \%$ below that at $\mathrm{pH} 5 \cdot 1$; the highest specific activity was obtained at $\mathrm{pH}$ 5.1-5.2 (Table 2, Expt. 44).

Precipitates of higher specific activity were obtained by decreasing the total protein concentration of the mixtures but great losses of plasminogen occurred at total protein concentrations lower than $0.05 \mathrm{~g} . / 100 \mathrm{ml}$. The optimum conditions for the 
precipitation of fraction $\mathrm{P} 3$ were $\mathrm{pH} 5 \cdot 1-5 \cdot 2$, I $0.02-0.04$, and protein $0.3-0.5 \mathrm{~g} . / 100 \mathrm{ml}$. Over a number of preparations the activity recovered in this fraction varied between 70 and $95 \%$ of that of fraction $\mathrm{P} 2$ and the specific activity varied between 450 and 550.

\section{Purification of the plasminogen of the fraction $\mathrm{P} 3$ by phase separation}

Initial observations. The fractions obtained in the previous steps contain a large amount of lipoprotein, and an attempt was made to remove some of the lipids by freezing with ether $(30 \%, v / v)$ at $-25^{\circ}$ and thawing in cold water (McFarlane, 1942). Fraction P3 was treated in this manner but the mixtures were centrifuged at $0^{\circ}$ immeriately after thawing, instead of allowing them to stand for 6-8 hr. at room temperature as originally described.

When solutions of fraction $\mathrm{P3}$ in phosphate- $\mathrm{NaCl}$ were treated in this way most of the mixture had a gel-like appearance, only a small amount of clear solution separating at the bottom of the bottle. When the mixture was reshaken and warmed to room temperature, a clear solution was obtained after centrifuging, with little gel-like material remaining. By simply shaking solutions with excess of ether several times at $0-4^{\circ}$ without freczing, a layer of material separated between the undissolved ether at the top and the bottom layer of protein solution, and after centrifuging at $0^{\circ}$ this intermediate layer packed to givo a gel-like appearance. When a bottom layer prepared at $-3^{\circ}$ to $0^{\circ}$ and separated from the mixture immediately after centrifuging was placed in a closed container and warmed to room temperature, further material separated and rose to the surface.

The influence of these procedures on the plasminogen activity of the bottom layer was examined under various conditions.

Procedure for preparing the fraction $B L$. Ether $(200 \mathrm{ml}$. was added to $100 \mathrm{ml}$. of protein solution at $4^{\circ}$ and the mixture was cooled to $0^{\circ}$ in a bath at $-3 \cdot 5^{\circ}$. The mixture was then shaken at intervals whilst cooling to the final temperature selected, during 90-120 min. After centrifuging, the bottom layer was siphoned off and the plasminogen (fraction BL) was precipitated from it by dialysing overnight against distilled water and then for $24 \mathrm{hr}$. against two changes of acetate-phosphate buffer, $\mathrm{pH} 5 \cdot 15$, I 0.03 . When the protein concentration was above $0.2 \mathrm{~g} . /$ $100 \mathrm{ml}$. the plasminogen was precipitated quantitatively from the bottom layer by adjusting the $\mathrm{pH}$ to $5 \cdot 15$ with $0.05 \mathrm{~m}$-acetic acid and diluting with $3 \mathrm{vol}$. of water, omitting the dialysis step.

Factors influencing the yield and specific activity of the plasminogen of the fraction $B L$. If after being treated at $-3^{\circ}$ the mixture was warmed before centrifuging, the amount of protein in fraction BL increased and the specific activity of the plasminogen decreased (Table 3).

With phosphate-NaCl buffers the yield of protein increased on increasing the $\mathrm{pH}$ throughout the ranges studied and the specific activity of the preparations remained fairly constant up to $\mathrm{pH} \mathbf{7 \cdot 6}$ $8 \cdot 0$, but decreased at $\mathrm{pH}$ values higher than 8 . At $\mathrm{pH}$ values below $6 \cdot 4$ the yield of protein and activity was very low and there was no increase in specific activity. With phosphate buffers not containing $\mathrm{NaCl}$, the protein yield and the specific activity of preparations increased with $\mathrm{pH}$ but no preparation having a specific activity higher than the starting material was obtained.

On decreasing $I$ from 0.3 to 0.1 the recovery of total protein and activity decreased and the specific activity increased. On increasing the protein concentration used for preparing the bottom layer the specific activity of the resulting fraction BL tended to decrease and the recovery of protein fell. The protein concentration giving the highest specific activity at the final temporature of $0^{\circ}$ appeared to be about $0 \cdot 1-0 \cdot 26 \mathrm{~g} . / 100 \mathrm{ml}$.

When a bottom layer separated at $-3^{\circ}$ was placed in a closed container and warmed to room temperature for $4 \mathrm{hr}$. a second bottom layer again separated and the specific activity of the precipitate from this was $26 \%$ higher than that from the first bottom layer obtained without warming to room temperature. The total activity in the second bottom layer was $58 \%$ of that in the first.

For routine purification plasminogen solutions (fraction P 3) containing 0.5-1 g. of protein/100 ml. were prepared in phosphate- $\mathrm{NaCl}$ buffer, $\mathrm{pH} 8$, I 0.2 , separated as described at $-3^{\circ}$ and then warmed to $15^{\circ}$ before centrifuging. The bottom layer obtained was adjusted to $\mathrm{pH} 5 \cdot 15$ with $0.05 \mathrm{~m}$-acetic acid, and diluted with 3 vol. of water at $0^{\circ}$.

\section{Purification of plasminogen with cellulose resin}

Plasminogen was adsorbed on to dicthylaminoethylcellulose and eluted with ammonium acetate buffer containing certain amino acids, by a batch procedure. The protein, fraction P3 or BL dissolved in $0.02 \mathrm{M}$-ammonium acetate buffer, was mixed with resin and stirred at intervals during $60 \mathrm{~min}$., and the resin filtered off on a Buchner funnel and washed several times with buffer. The washed resin was suspended in an eluent solution for $30 \mathrm{~min}$. and then filtered as before. It was necessary to saturate the resin with protein to obtain reproducible results. The sample of resin used was saturated by $130-150 \mathrm{mg}$. of protein/g. of resin, and eluted with $25 \mathrm{ml}$. of eluent/g.

Lysine and arginine $(0.2 \mathrm{M})$ were both very effective eluents (Table 4), yielding more than $90 \%$ of the total activity applied, whereas $\epsilon$-aminohexanoic acid $(0.5 \mathrm{M})$ eluted only $50 \%$. Here the increase in the specific activity was about 2.5 times that of the starting material in all instances. With $0.1 \mathrm{M}$-lysine in the eluent, the specific activity of the eluate was usually five to seven times that of the fraction applied.

The eluates (fraction $R$ ) obtained from fractions BL and P3 with 0.1 M-lysine in the eluent showed the same order of increase in the specific activity compared with the starting materials; $80-100 \%$ of the total activity was recovered from fraction BL and $70 \%$ or more from fraction P3.

The yields and specific activities of the different fractions are shown in Table 5. 
Table 4. Effect of $\epsilon$-aminohexanoic acid, lysine and arginine on the elution of plasminogen from diethylaminoethylcellulose resin

Specific activities of the starting material were 600,480 and 1320 for P3, R5; P3, R6 and BL, R6 respectively. Yield of $\mathrm{N}$ and activity are relative to the starting material.

$\begin{array}{cccccc}\begin{array}{c}\text { Expt. } \\ \text { no. }\end{array} & \begin{array}{c}\text { Starting } \\ \text { material }\end{array} & \begin{array}{c}\text { Eluate } \\ \text { C-Aminohexanoic }\end{array} & \begin{array}{c}\text { Specific } \\ \text { activity }\end{array} & \begin{array}{c}\text { Yield of } N \\ \text { (\%) }\end{array} & \begin{array}{c}\text { Activity } \\ \text { (\%) }\end{array} \\ \text { R5 } & \text { P3 } & 1410 & 21 & 50 \\ & & \begin{array}{c}\text { Lys (0.5 M) } \\ \text { Ly.2M) }\end{array} & 1400 & 41 & 95 \\ & & \text { Arg (0.2M) } & 1280 & 42 & 91 \\ \text { R6 } & \text { P3 } & \text { Lys (0.1 M) } & 3600 & 10 & 71 \\ & \text { BL } & \text { Lys (0.1 M) } & 6000 & 17 & 80\end{array}$

Table 5. Yields and specific activities of the plasminogen fractions

\begin{tabular}{|c|c|c|c|c|c|}
\hline \multirow[b]{2}{*}{ Fraction } & \multirow[b]{2}{*}{$\begin{array}{l}\mathrm{N} \text { (mg./l. } \\
\text { of plasma) }\end{array}$} & \multirow[b]{2}{*}{$\begin{array}{l}\text { Specific } \\
\text { activity }\end{array}$} & \multicolumn{2}{|c|}{ Activity } & \multirow[b]{2}{*}{$\begin{array}{l}\text { Purification } \\
\text { factor* }\end{array}$} \\
\hline & & & $\begin{array}{c}\text { (units/l. of } \\
\text { plasma) }\end{array}$ & $\begin{array}{c}\text { Yield* } \\
(\%)\end{array}$ & \\
\hline $\begin{array}{l}\text { Plauma } \\
\text { P1 } \\
\text { P2 } \\
\text { P3 } \\
\text { BL } \ddagger \\
\text { R }\end{array}$ & $\begin{array}{l}7500 \\
620 \\
410 \\
150 \\
80-100 \\
10-20\end{array}$ & $\begin{array}{l}18 \dagger \\
185 \\
250 \\
450-550 \\
690-900 \\
3600-6000\end{array}$ & $\begin{array}{l}140000 \dagger \\
113000 \\
110000 \\
65000-85000 \\
63000-84000 \\
60000-83000\end{array}$ & $\begin{array}{l}100 \\
80 \dagger \\
78 \\
46-61 \\
45-60 \\
36-59\end{array}$ & $\begin{array}{c}1 \\
10 \\
15 \\
30 \\
45 \\
190-315\end{array}$ \\
\hline
\end{tabular}

\section{Electrophoresis of fractions}

The results are shown in Fig. 1. It is difficult at present to correlate the difference in activity of the preparations with any particular changes in their electrophoretic components. Fraction $\mathbf{P l}$ is a complex mixture which probably contains almost all the main electrophoretic components of plasma. When fraction $\mathrm{Pl}$ is compared with fractions $\mathbf{P 2}$ and $P 3$, respectively, an increase in the proportion of the main peak of the electrophoretic pattern is apparent. The increase in the proportion of this peak was accompanied by an increase in the specific activity from 180 in fraction $P 1$ to 270 and 480 respectively in fractions $P 2$ and $P 3$. However, the pattern of fraction $B L$, which had a specific activity of 1500 , did not show any striking difference from that of fraction P 3; both fractions containing at least three components.

The solution of fraction $R$ in phosphate buffer became increasingly opalescent in the course of the run and this made the observation of the electrophoretic pattern very difficult. However, when this fraction was run in glycine- $\mathrm{NaOH}-\mathrm{NaCl}$ buffer no opalescence occurred, the preparation having at least two electrophoretic components. The reason for the development of the opalescence in this fraction is obscure. It might result from an interaction between the phosphate ion and a protein during the electrophoresis. Kline a

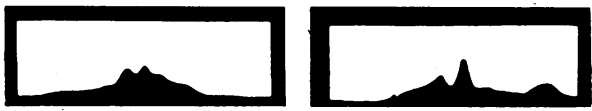

b
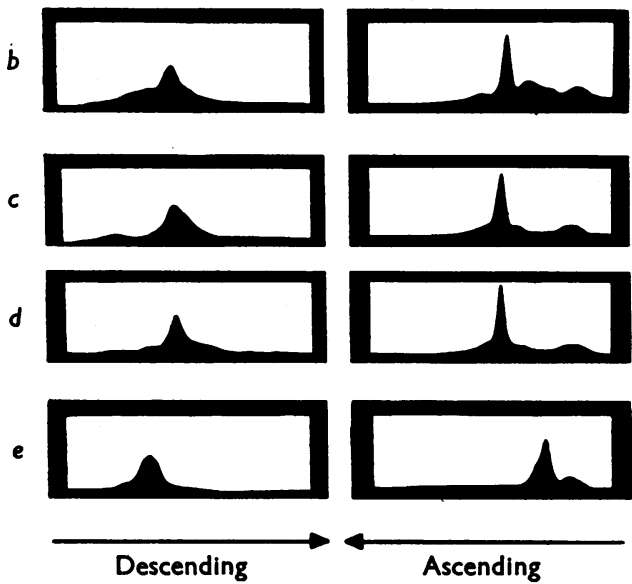

Fig. 1. Electrophoresis of plasminogen fractions. The experiments were run in phosphate buffor, $\mathrm{pH} 8, I \quad 0.2$ $(a-d)$, or in glycine-NaOH-NaCl buffer, pH 0.2, I 0.1 (e). (a) Fraction P1, protein $1.75 \mathrm{~g} . / 100 \mathrm{ml}$; (b) fraction P2, protein $1.65 \mathrm{~g} . / 100 \mathrm{ml}$.; (c) fraction P3, protein $1.16 \mathrm{~g} . /$ $100 \mathrm{ml}$; (d) fraction BL, precipitated from a bottom layer prepared at $-3^{\circ}$ and $-3^{\circ}$ (separation and final temperature respectively), protein $1.36 \mathrm{~g} . / 100 \mathrm{ml}$.; (e) fraction $\mathbf{R}$, protein $1.1 \mathrm{~g} . / 100 \mathrm{ml}$. 
(1953) observed that a small amount of phosphate caused precipitation in his preparations of purified plasminogen.

\section{DISCUSSION}

One of the main difficulties encountered (Remmert \& Cohen, 1949; Kline, 1953) in attempting to purify plasminogen is its tendency to coprecipitate with other proteins. In the present investigations the tendency to co-precipitate has been used to prepare fraction P2. The activity recovered in this fraction was greater from crude plasminogen (fraction $\mathrm{P} 1$ ) precipitated at $\mathrm{pH} \mathrm{5 \cdot 3-}$ 5.4 than at $\mathrm{pH} 5 \cdot 15$, although these contained similar amounts of plasminogen. Also, when fraction $P 1$ was first fractionated in acetatephosphate buffer at pH 5.0 and subsequently in citrate buffer at $\mathrm{pH} 6 \cdot 5$, no precipitate formed on adjusting the conditions to those normally producing a separation of fraction $\mathrm{P} 2$. These observations suggest that protein necessary for coprecipitating with plasminogen at $\mathrm{pH} 6.5$ remains in solution at $\mathrm{pH} 5 \cdot 0-5 \cdot 15$.

In the separation of fractions $P 1$ and $P 2$, the amount of ether present was less than that required to saturate the aqueous phase, and the precipitated protein always sedimented. In preparing the 'bottom layer', a considerable excess of ether was present and separated protein rose to the surface to form a new gel-like phase, with physical properties very different from those of the precipitates obtained previously. This suggests that, in the presence of excess of ether under these conditions, the ether and some of the proteins may interact with consequent separation of material with a density lower than that of the aqueous solution. Whatever the mechanism and interpretation of these phenomena, this procedure yielded plasminogen preparations of increased specific activity which dissolved to give very clear solutions.

Most previous workers have described their preparations as 'so many times purified relative to serum' with no indications of how these calculations wero made.

Remmert \& Cohen (1949) described their plasminogen as purified 136-165-fold relative to serum but do not state the yield. Christensen \& Smith (1950) estimated a purification of 250 -fold for their plasminogen with yields varying from 10 to $100 \%$ of the total activity, the average being $30 \%$; Kline (1953) a 425-fold purification with a yield of $33 \%$; Hagan et al. (1960) a 300-400-fold purification without stating yield; and Wallen \& Bergström (1960) a 20-30-fold purification compared with the starting material, Cohn's fraction II + III. Plasminogen is concentrated in this fraction, which contains $25 \%$ of the total protein of plasma (Oncley, Melin, Richert, Cameron \& Gross, 1949). If it is assumed that fraction II + III contains all the plasminogen of plasma, Wallen \& Bergström achieved 80-120-fold purification relative to the plasma.

It is difficult to relate the activity of a plasminogen preparation to that of serum directly, since serum contains potent plasmin inhibitors whose effect will vary with the dilution of serum used in any assay. It is possible that a similar limitation applies to the first plasminogen fraction obtained during purification but in these circumstances the amount of inhibitor, if present, is much lower.

No attempt was made directly to estimate the amount of plasminogen in plasma. An approximate estimate of the degree of purification achieved was obtained on the assumption that about $20 \%$ of the plasminogen precipitates with the fibrinogen fraction, (M. E. Mackay, unpublished work) and that all the plasminogen in the solution $S 1$ is precipitated in fraction P 1 . Since the protein content of the plasma used was about $46 \mathrm{~g} . / \mathrm{l}$. and the protein obtained from it in fraction $P 1$, with a specific activity of 180-190, corresponds to $3 \cdot 8 \mathrm{~g}$./l. of plasma, the factor for $\mathrm{Pl}$ is 10 , indicating a specific activity of 18 in whole plasma. With $0.1 \mathrm{~m}$-lysine in the eluent the potency of batch eluates lay between 3600 and 6000 , corresponding to purification factors of $190-315$ relative to plasma; the recovery of total activity was usually not less than $70 \%$ that of fraction $\mathrm{P} 1$.

The preparations obtained compare favourably in several respects with others described in the literature, not only because of the high yield but also because they are soluble at neutral pH. However, no comparison between the specific activity of the preparation described here and the results of other workers can be made because of the different assay procedures that have been used.

The properties of the proteins obtained here may be nearer to those of the native proteins than is the case with acid-alkali-treated plasminogen preparations.

\section{SUMMARY}

1. Plasminogen was purified from out-dated human plasma. A crude plasminogen (fraction $P 1$ ) was first precipitated after the removal of fibrinogen from plasma at $\mathrm{pH} 5 \cdot 3$, and a fraction $\mathrm{P} 2$ obtained from this by treatment with citrate buffer.

2. Fraction $\mathrm{P} 2$ was dissolved in acetatephosphate buffer, $\mathrm{pH} 4 \cdot 0$, and the plasminogen precipitated from the solution by adjusting it to $\mathrm{pH} 5 \cdot 15$, to give fraction $\mathrm{P} 3$.

3. By dissolving the fraction $\mathbf{P} 3$ in phosphatesodium chloride buffer, $\mathrm{pH} 8.0$, and shaking the solution with excess of ether at $-3^{\circ}$, lipid material and some inactive protein were removed, and plasminogen precipitated from the aqueous layer at $\mathrm{pH} 5 \cdot 15$ to give fraction $\mathrm{BL}$. 
4. From both fractions $P 3$ and BL purified plasminogen fractions were obtained by batch adsorption on to diethylaminoethylcellulose resin followed by elution with lysine-containing buffers. The eluates obtained by the batch adsorption of fraction $B L$ (fraction $R$ ) had a potency 190-315 times that of plasma, the preparation being soluble at neutral $\mathrm{pH}$.

This work was done during the tenure of a British Council Scholarship (1957-59) and a grant from the Consejo Nacional de Investigaciones Cientifícas y Técnicas, (Buenos Aires, Argentina) (1959-60). The author is indebted to Dr R. A. Kelkwick for his helpful adrice and criticism and for his invaluable assistance in the preparation of the manuscript and to Mr Brian Jordan for much technical assietance. Thanks are due to Dr A. E. Pearco for the facilities made available for an electrophoresis run to be made in the Perkin-Elmer apparatus.

\title{
REFERENCES
}

Alkjaersig, N., Fletcher, P. \& Sherry, S. (1958). J. biol. Chem. 233, 81.

Chibnall, A., Rees, M. W. \& Williams, E. F. (1943). Biochem. J. 37, 354.

1

Biochem. J. (1962) 82, 247

\section{The Reaction of Normal Adult Human Haemoglobin with Heavy-Metal Reagents}

\author{
BY R. CECIL AND N. S. SNOW \\ Department of Biochemistry, University of Oxford
}

(Received 31 May 1961)

All the mammalian haemoglobins which have so far been examined contain SH groups that form mercaptides immediately on tho addition of heavy-metal reagents in the same way as simple thiols. Most, but not all, contain further SH groups that are unreactive in the native protein, but which react normally when the protein is denatured with acid or sodium dodecyl sulphate. It is not yet known why these groups are unreactive or what is their function.

The unreactive SH groups will react slowly with some heavy-metal reagents. This paper describes the reactions of mercuric chloride, phenylmercuric hydroxide, $p$-chloromercuribenzenesulphonate and silver nitrate with the SH groups of normal adult human haemoglobin in its various forms. Allison \& Cecil (1958) have shown that this protein has a total of $6 \mathrm{SH}$ groups/molecule, 2.2 of which are normally reactive and the remainder unreactive until the protein is denatured.
Christensen, L. R. \& Smith, D. R. (1950). Proc. Soc. exp. Biol., N.Y., 74, 840 .

Hagan, J. J., Ablondi, F. B. \& De Renzo, F. C. (1960). J. biol. Chem. 235, 1005.

Kekwick, R. A. \& Mackay, M. E. (1954). Spec. Rep. Ser. med. Res. Coun., Lond. no. 286.

Kekwick, R. A., Mackay, M. F., Nance, M. H. \& Record, B. R. (1955). Biochem. J. 60, 671.

olthoff, I. M. (1937). Acid-Base Indicaturs, pp. 249, 258. New York: The Macmillan Co.

Ma, T. \& Zuazaga, G. (1942). Industr. Engng Chem. (Anal.), 14, 280.

McFarlane, A. S. (1942). Nature, Lond., 149, 439.

Miller, G. L. \& Golder, R. H. (1950). Arch. Biochem. 29, 420. Milstone, H. (1941). J. Immunol. 42, 109.

Oncley, J. L., Melin, L., Richert, D. A., Cameron, J. W. \& Gross, P. M., jun. (1949). J. Amer. chem. Soc. 71, 541.

Philpot, J. St L. (1938). Nature, Lond., 141, 283.

Remmert, L. F. \& Cohen, P. P. (1949). J. biol. Chem. 181, 431.

Shulman, S., Alkjaersig, N. \& Sherry, S. (1958). J. biol. Chem. 233, 91.

Tiselius, A. (1937). Trans. Faraday Soc. 33, 524

Wallen, P. \& Bergström, K. (1960). Acta chem. scand. 14, 217. 